\title{
Beowulf and Archaeology: Megaliths Imagined and Encountered in Early Medieval Europe
}

\author{
Howard Williams \\ Department of History and Archaeology, University of Chester, Chester, UK.
}

Williams, H. (in press 2015). Beowulf and archaeology: megaliths imagined and encountered in Early Medieval Europe, in M. Diaz-Guardamino Uribe, L. García Sanjuán and D. Wheatley (eds) The Lives of Prehistoric Monuments in Iron Age, Roman and Medieval Europe, Oxford: Oxford University Press.

\begin{abstract}
The dragon's lair in the epic Anglo-Saxon poem Beowulf has been widely interpreted to reflect engagement with Neolithic megalithic architecture. Embodying the poet's sense of the past, the stone barrow (Old English: stänbeorh) of the dragon has been taken to reveal mythological and legendary attributions to megalithic monuments as the works of giants and haunts of dragons in the early medieval world. This chapter reconsiders this argument, showing how the dragon's mound invoked a biography of successive pasts and significances as treasure hoard, monstrous dwelling, place of exile, theft, conflict and death. Only subsequently does the mound serve as the starting-point for the funeral of Beowulf involving his cremation ceremony and mound-raising nearby. The biography of the dragon's barrow is a literary one, in which inherited prehistoric megaliths were counter-tombs, antithetical to contemporary stone architectures containing the bodies of kings, queens and the relics of saints.
\end{abstract}

\section{Keywords}

Anglo-Saxon church, archaeology, Beowulf, barrow, crypt, mausoleum, megalithic architecture, memory, mortuary archaeology

\section{Introduction}

Since the mid- $19^{\text {th }}$ century, the poem Beowulf has long been a quarry for inspiration, analogy and insight for those exploring the archaeology of early medieval Britain and Scandinavia (Cramp 1957; Hills 1997; Webster 1998; Owen-Crocker 2000). The dialogue of archaeology and poem has been employed to explore a range of early medieval social practices and structures: the production and circulation of weapons and armour through inheritance and gift-giving, the role of vessels and feasting practices, hall-building and ceremony, the hoarding of treasure and various dimensions of funerary practice including barrow-burial, boat-burial and cremation. In discussing many of these practices, scholars have recently pointed to the sense of the past in the poem as a practice-orientated form of social memory, investigating both heroic poetry and the ceremonial use of material culture, monuments, architectures and landscapes identified in poetry and archaeological evidence as distinct but related technologies of remembrance within the hierarchical Christian Anglo-Saxon kingdoms that emerge during the mid- to late $7^{\text {th }}$ century AD (Williams $1998 ; 2006 ; 2011 \mathrm{a} \&$ b; Owen-Crocker 2000; Semple 2013). In this fashion, the assertions of legitimacy and identities by early medieval elites, including their claims to (and over) land, power and people, were performed through the ritualised reuse, appropriation and naming of ancient monuments and their deployment within rituals and oral performances, including poetry (Semple 2013; see also Price 2010). The locations and immediate environs of major later Anglo-Saxon churches and elite residences, and the maritime and land routes connecting them, provided the dramaturgical and ritualised settings and media by which social memories 
were transmitted and reproduced. Landmarks such as ancient monuments were actively integrated through reuse for a variety of functions from burial to assembly (Williams 2006; Langlands and Reynolds 2011; Semple 2013). In particular, Sarah Semple's (2013) important interdisciplinary survey and analysis of Anglo-Saxon perceptions and reuse of prehistoric monuments from the 5th to the 11th centuries $\mathrm{AD}$, reveals the variegated and shifting perceptions of prehistoric monuments revealed by later Anglo-Saxon text, manuscript illustrations, place-names and archaeological evidence (see also Semple 1998; 2004).

While building on this research, this paper tackles afresh the striking instance, often cited but rarely dealt with in any depth or scope, of the portray of an ancient stone barrow in the late 10th or early eleventh-century poem Beowulf. This epic text is the longest English verse source to survive from prior to the Norman conquest (AD 1066) and most likely enshrines a far earlier set of oral poetry circulating during the seventh and eighth centuries if not earlier still. Drawing on John Hines's approach to the relationship between Anglo-Saxon literature and archaeology (Hines 2008; 2013) and Sarah Semple's specific discussions of ancient monuments as places of fear and torment in the later Anglo-Saxon landscape (Semple 1998; 2004; 2013), I utilise two familiar verse translations (Bradley 1982; Heaney 2002, drawing quotations from the latter) to interrogate what the poem reveals about later Anglo-Saxon perceptions of megalithic structures and their cultural biographies.

\section{The Dragon's Mound in Beowulf}

For those unfamiliar with the story, it is important to begin with a brief account of how the dragon's mound is key within the structure of the poem. As a young hero, Beowulf travels over the sea to Denmark where he defeats the monster Grendel who had plagued King Hrothgar's hall: Heorot. The hero then defeat's Grendel's mother within her cave. As an old king, having ruled his land for fifty winters in Geatland (line 2209), a new subterranean threat emerges from the wilderness surrounding his own kingdom: a dragon. The dragon's mound is the setting for Beowulf's third and final encounter with a monster and his subsequent death and funeral (lines 2200-3182).

The poem Beowulf tells us that the dragon's lair was a stony barrow (Old English: stänbeorh) built by an ancient race of giants on a headland by the sea, subsequently sought out and guarded by the dragon. The barrow was disturbed by an exile from Beowulf's kingdom who retrieved a goblet to use as a gift for Beowulf, his lord, to appease and atone for unnamed crimes. As recipient of the cursed gift, Beowulf and his kingdom receive the wrath of the dragon who, upon waking, realises the treasure is missing and exacts revenge through aerial fiery destruction of the kingdom's halls (lines 2312-2324). Guided by the thief and accompanied by a small retinue, Beowulf goes to the barrow and, leaving his companions above-ground, alone enters into the mound via the hidden path to slay the dragon. His companions flee but one of them, Wiglaf, enters the mound to assist his lord in the fight. Beowulf and Wiglaf slay the beast but the hero dies from his wounds. Under Wiglaf's direction, Beowulf is cremated on a nearby headland and a mound is raised over the pyre-site as a landmark for seafarers. The cursed treasure from the dragon's mound - described as consisting of weapons and armour, feasting gear and a standard - is buried with the hero and king; the riches are not divided and circulated among Beowulf's people.

Since the Victorian era, it has been recognised that the poem might be describing a Neolithic passage grave or chambered tomb. This interpretation has received repeated but brief commentaries by many discussants of the relationship between the poem and archaeology (e.g. Wright 1847; Cramp 1957; Hills 1997; Webster 1998). Most recently, Semple (2013) 
cites Beowulf as a key source in relation to a range of other literary, documentary, visual and toponymic evidence that reveals how ancient monuments were perceived as places of both fame and infamy in the Christian later Anglo-Saxon landscape (here taken to refer to the late seventh to eleventh centuries AD). The argument that the dragon's mound might be a Neolithic monument finds support from the concrete evidence that early medieval burials of the late 5th to late 7th century AD could be deliberately inserted into, and situated around, Neolithic long barrows, a practice that was part of a wider funerary reuse of prehistoric and Roman-period ruins and monuments (see Williams 1998; 2006; Semple 1998; 2013). Furthermore, toponymic evidence reveals how striking megalithic monuments, notably Wayland's Smithy, Oxfordshire, could be afforded ambivalent legendary associations (Grinsell 1991; Owen-Crocker 2000, 62-3). Beowulf is thus taken to provide a key case study of a wider phenomenon: the mythological and legendary afterlives of megaliths in the medieval world, places of fear rather than veneration (see also Holtorf 1996; Hutton 2009; Vejby 2012). The remainder of this chapter seeks to query and enhance this well-established argument by exploring the biography and materiality of the dragon's mound as portrayed in the poem.

\section{A Biography for the Dragon's Mound}

While archaeologists have tended to explore the archaeological biographies of megalithic monuments (e.g. Holtorf 1996), I here want to apply this approach to the poem itself. The dragon's mound is portrayed as on the periphery of Beowulf's kingdom - like Grendel and Grendel's mother's mere was for Hrothgar's - a liminal place physically and conceptually on the very edge of the human world, 'on a wide headland/ close to the waves' (lines 2243-4) near the cliff top (line 2417). The mound and its landscape setting reveal its multi-temporal quality in the poem; we are told of at least six phases of use:

i. the location was selected and the stone barrow made by the Last Survivor - the only remaining member of the ancient race - as a cache to contain his dead people's treasures (lines 2242-2269);

ii. sometime later, it was sought out and became the habitation for a sleeping dragon guarding the treasure (lines 2270-75);

iii. three hundred years later it became the landscape where only an exile dared to venture to steal a goblet, thus rousing the dragon to vengeance (lines 2214-18);

iv. in response, it became a place of conflict and death where Beowulf and Wiglaf encountered the dragon and both the dragon and Beowulf perished (lines 2410-2820);

v. it became a funerary landscape comprised of at least three commemorative nodes:

a. the empty stone barrow from whence the dragon's corpse and the treasure were taken (lines 3129-31);

b. the site of Beowulf's cremation over which a mound was raised and in which the dragon's treasure was interred: a landmark for seafarers (lines 3136-3182);

c. the sea-cliff over which the dragon's body was consigned to the waves (line 3131).

vi. at Beowulf's funeral, a lamenting woman foresaw a future in which the Geatish kingdom was destroyed: imagining cataclysmic events that created an abandoned set of monuments on the headland: the dragon's mound and Beowulf's counterpoised (3150-55).

This 'monument biography' rendered the dragon's mound a mnemonic time-mark simultaneously famous and infamous - linking together each biographical stage from its building to the poet's present: a cache of giants' treasure, a dragon's den, a place of exiles and theft, a place for heroic conflict and death and finally a component in the mortuary drama 
of the hero's funeral. For the poet and his audience, the mound is situated in a literary topography of memory in the Scandinavian past and simultaneously tangible through innumerable prehistoric monument complexes within the environs of numerous early medieval ecclesiastical and aristocratic central places across Anglo-Saxon England (Semple 2013: 108-42). Hence, the mnemonic power of this poetic landscape lay in its mutability and replication across the coastal and maritime Anglo-Saxon royal and ecclesiastical landscapes. In these environments, ancient monuments were suitable settings for legendary hagiographic and heroic deeds against demonic forces and understood relationally with regard to contemporary megalithic architectures of mausolea, crypts and other hypogeal and semihypogeal structures (Williams 2006; Semple 2013).

\section{The Mound's Architectural Materiality}

To further understand the significance of the mound, we must also engage with its lithic materiality. The poem describes how the mound contained 'the steep vaults of a stone-roofed barrow' (line 2213), 'earth-house' (line 2232), 'earth-vault' (line 2410), 'underground barrow' (line 2411) and 'treasure-lodge' (line 2830).

This was a secret and fearful underground space entered via a prominent threshold. Yet the thief enters via a 'hidden passage, unknown to men' (lines 2213-4); Beowulf enters alone 'under the crag' (line 2541) along 'no coward path' (line 2541). Within were vaults (lines 2323 and 3128) and water: '... a stone arch and a gushing stream/ that burst from the barrow, blazing and wafting/a deadly heat' (line 2545-7). Following his fight with the dragon, Beowulf apprehends 'those gigantic stones, saw how the earthwork / was braced with arches built over columns (lines 2719-20), a 'rock-piled roof' (line 2755). The passage to the chamber was presumably dark and constricted, traversed thrice only by individuals (the thief, Beowulf and then Wiglaf) and after the dragon's death by a select group of eight who entered with torches (lines 3120-3123, 3125). The dragon does not explicitly use this route to enter and leave the mound. A further component of the mound was a plinth or seat beside the earthwork upon which Beowulf's dying body is sat whilst Wiglaf retrieves the treasure (line 2717). This is surely in daylight and beside the entrance for when Wiglaf re-enters, it is on passing the plinth/seat that he sees the treasure (line 2756).

All these material references are generic, yet scholars have been all too keen to confine the poem to a Neolithic megalithic straightjacket. As such, this is very much a Victorian contrivance, equating a specific architectural typology to verify the historicity of one dimension of the poem. My point is not to deny that a megalithic monument might have inspired the poem: the chambers, passages, portals and kerbs make Neolithic monuments one plausible source of influence (see Scarre 2007, 76-81). In particular, the false portals of Cotswold-Severn chambered tombs like Belas Knap (Gloucestershire) or West Kennett (Wiltshire) equate well with the idea of an impassable threshold, a hidden passage known only to the thief. Yet it must be remembered that megalithic monuments find close parallel with Beowulf only through their post-excavation reconstruction during the later nineteenth and twentieth centuries. Before then, far fewer megaliths would have had visible passages and chambers free of earth and accessible in the fashion the poem describes.

Early medieval populations in Britain would, however, have experienced of a wider range of other ancient subterranean and semi-subterranean spaces: Iron Age souterrains, Romanperiod temples, mausolea, bathhouses, underfloor heating systems, aqueducts and drains (Hunter 1974, 35). Indeed, there is clear archaeological evidence that some of these were reused for burial, as were prehistoric burial mounds, within Christian later Anglo-Saxon 
ecclesiastical landscapes. For example the reuse of a Roman mausoleum at Wells as an ossuary and in turn by a mortuary chapel associated with the Anglo-Saxon minster would undoubtedly have involved the discovery and manipulation of ancient human remains as well as the translation of more recently interred bodies (Rodwell 2001, 39-50, 55-60, 75-85). Furthermore, just because the poem is explicit in referring to architecture does not rule out the possibility that the natural geology of cave systems might have inspired such a description to the early medieval mind: before the invention of geology we should not presume that a simple division between 'nature' and 'human-made' structures was readily apprehended for prehistoric and early historic communities (see Bradley 1998).

Equally important is to recognise that Beowulf uses the Old English words hlaw and beorg interchangeably and both might refer to 'burial mounds' (Semple 2013, 158). However, these words need not imply an exclusive funerary function to earthworks given this attribution (see e.g. Hines 2008, 64; Thompson 2004, 106). Therefore the use of these terms in no way implies an exclusive comprehension of the dragon's barrow as a funerary monument. Furthermore, Semple (2013, 144-5) notes Beowulf uses the distinctive term boga (stonebows/vaults) suggesting a specific understanding of this structure that differs from other earthen and stone mounds.

Once we remove the Neolithic straightjacket on our interpretations, it becomes clear that broadly contemporary church stone-built architecture of the late $7^{\text {th }}$ to $11^{\text {th }}$ centuries, itself drawing materials and inspiration from Roman stonework, provides equally close parallels and likely inspiration for the poet's account of the dragon's mound. Owen-Crocker (2000, 62) explicitly notes that the description of the stone barrow equates to a $7^{\text {th }}$ to $9^{\text {th }}$ century semi-subterranean or subterranean mausoleum, oratory or baptistery, but does not pursue the full implications of this possibility. Stone-built mausolea and crypts are known from the $7^{\text {th }}$ century, famously at Ripon and Hexham (e.g. Bidwell 2010), but the 'stone arches above firm columns' (lines 2718: Owen-Crocker 2000, 62) might allude to mortuary chapels and crypts that may have originally been free-standing structures like the multi-phased $8^{\text {th }}$ - and $9^{\text {th }}-$ century crypt from Repton (Owen-Crocker 2000, 64; Taylor 1987; Fig. 1a-c) or the sunkenfeatured two-cell structure excavated at Repton to the west of the church and interpreted as a middle Anglo-Saxon mortuary chapel converted into an early Viking-Age ossuary (Biddle and Kjølbye-Biddle 2001, 67-9). These hypogeal chambers could be megalithic, often comprised of reused Roman stone as in the crypt at Hexham (e.g. Bidwell 2010) as well as incorporating columns, lintel stones and vaults like those described in the poem (Taylor 1987; Biddle and Kjølbye-Biddle 2001). 

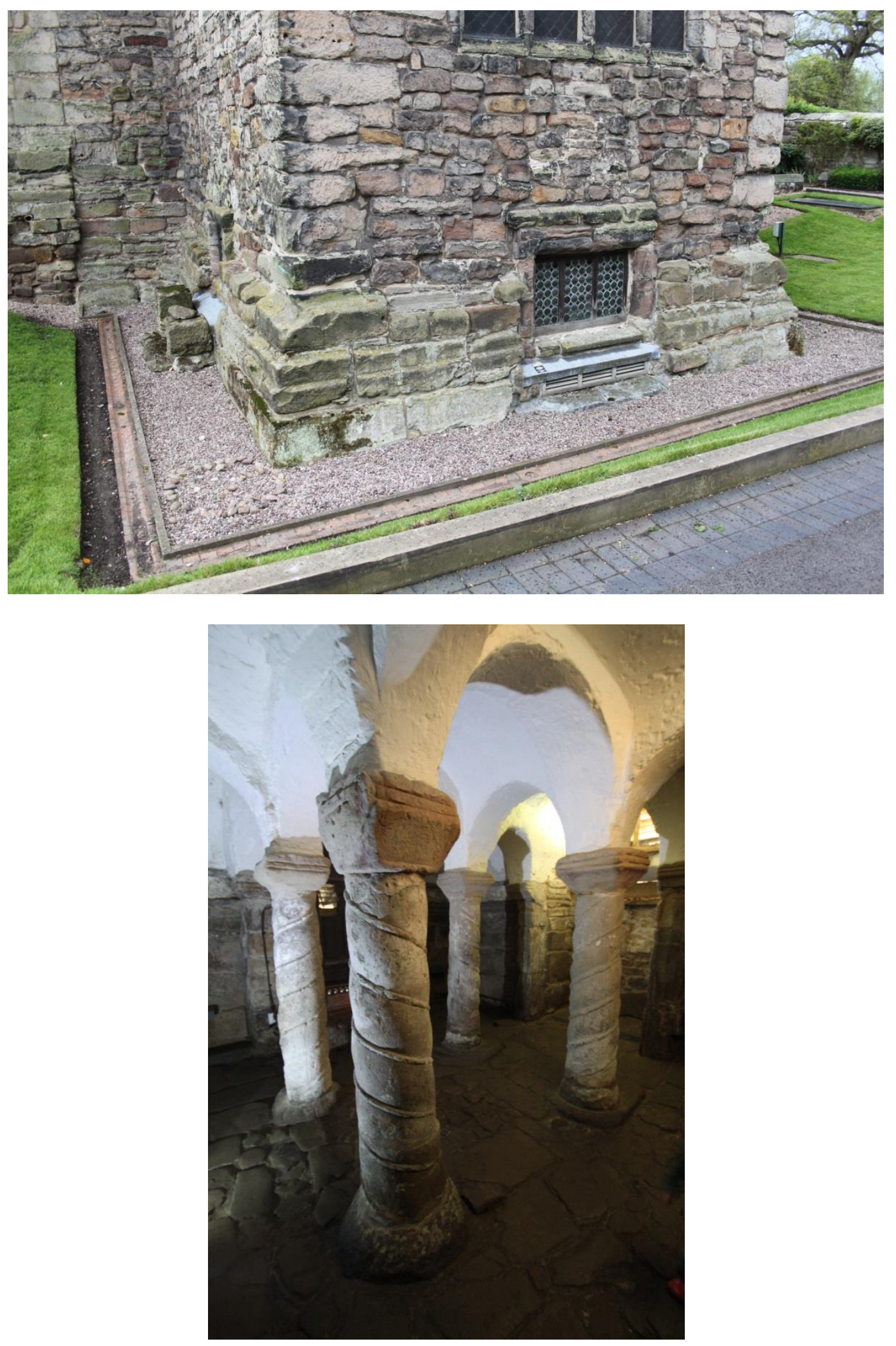


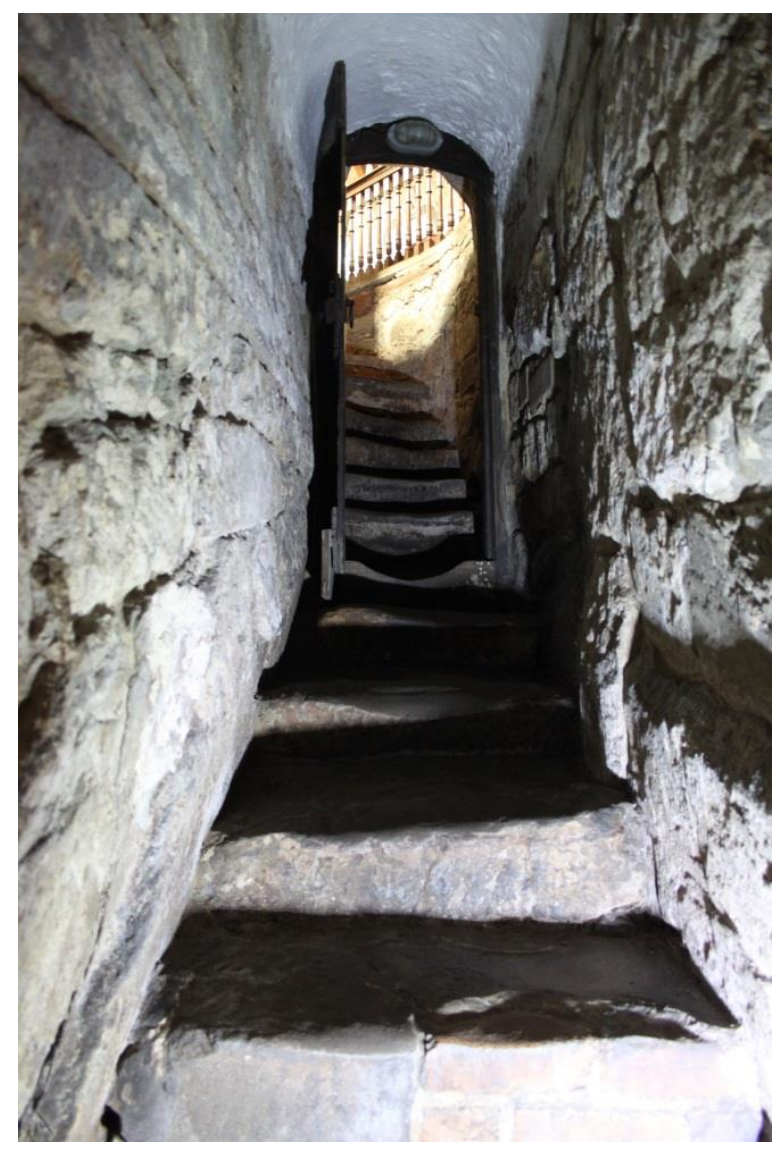

Figure 1a-c: Three views of the $8^{\text {th }}-9^{\text {th }}$ century crypt at Repton, Derbyshire, originally a freestanding baptistery and subsequently converted to a mortuary chapel for royal burial.

Photographs: Howard Williams, 2014.

The implied presence of water might be a further hint that the dragon's mound has multiple sources of inspiration, invoking either a natural cave or else a subterranean baptistery like that suggested for the pre-crypt phase of the structure at Repton (Taylor 1987) rather than a megalithic tomb built upon the ancient ground surface. Notably, the poem describes the dragon's barrow as the site of Beowulf's death and embarkation point for his funeral, but before this also a site where Beowulf is washed. Wiglaf somehow had ample water to hand in order to cleanse Beowulf's dying body on the stone seat outside the barrow's entrance (lines 2721-3). This might resonate with, and invert, the preparation of Christian bodies outside the portal of a church, or perhaps the washing of pilgrims seeking miraculous healing prior their descent into a crypt to encounter the relics of saints. Whether mausolea or oratories are being alluded to - a special sort of burial place for the very special dead and for royalty - the key point is that this is not simply another form of 'grave' (cf. Owen-Crocker 2000, 64). The hypogeum in the poem is an inhabited space of the dragon and a treasury, the inverse of places of pilgrimage and prayer in which the relics of the holy and other treasures are kept. Indeed, it might be entertained that the poem is reflecting a broader obsession with tombs and shrines as inhabited spaces in later Anglo-Saxon England, possibly drawing off pre-Christian concepts of the elite dead as resident in their tombs as well as contemporary engagements with the relics of saints (Williams 2011b; see also Williams forthcoming).

Old English poetry is regarded by Hines (2008) as 'persistently idealistic rather than realistic' and it is perhaps a distraction to (a) expect to find a precise parallel in terms of location, form 
and materiality to the dragon's barrow in the archaeological record and (b) interpret it in relation to any one category of archaeological monument. Yet the poetry is grounded in the world that was inhabited and experienced (Hines 2008, 70). In short, one cannot help entertain the possibility that the dragon's mound was portrayed as counterpoised with shrines and mausolea as much as the halls suggested by Semple (2013). Furthermore, as an inhabited space, but without a body, there is also the potential of allusion to Christ's tomb, insofar as the megalithic space is a sign of miraculous ascension, or at least, in broader terms, a witness onto God's instrumental design for the world.

\section{The Treasure's Materiality}

Webster $(2000,58)$ rightly states that the treasure in Beowulf is not a 'fossil memory of a Dark Age treasure' but instead a 'virtual treasure' operating as a moral concept (Webster $2000,59)$. I would take this argument further in two ways, by suggesting that the treasure was not primarily funerary but counter-funerary (cf. Owen-Crocker 2000: 118) and that the treasure was more than an idea: its materiality and biography were central to the narrative of Beowulf.

There is nothing in the poem to suggest a funerary deposit per se. Wiglaf sees 'wall-hangings that were a wonder to behold,/glittering gold spread across the ground ... packed with goblets and vessels from the past, tarnished and corroding. Rusty helmets/ all eaten away. Armbands everywhere,/artfully wrought' (lines 2758-63). Archaeologists have again created a typological straightjacket here, assuming a direct connection to furnished princely chambergraves like Mound 1 at Sutton Hoo (see Williams 2011). The plurality of artefacts does not imply selection for the grave, it is instead the opposite: an entire treasury that comprises all the trappings of a secular hall and all of its occupants. Moreover, the hoard is deposited not to mourn a dead individual but as the accumulated inheritance of an entire people (line 2235), who, through war, 'one by one they went down to death, leaving the joys of the hall' (lines, 2249-52). Also, it is oppositional to a funerary scene: the artefacts are deposited as an act of mourning but without any ceremony mentioned. Rather than a public funeral as received by Beowulf himself, the treasure is consigned by a solitary individual present: the Last Survivor who builds the mound specifically for the purpose of containing the treasure. The final piece of conclusive evidence is that no bodies were transported, dressed and decked with the artefacts. Indeed, like the hoard in Grendel's mere and Hrothgar's empty hall Heorot when deserted following Grendel's attack (lines 164-69; 412), the artefacts imply multiple absent bodies. Hence, the Lay of the Last Survivor is not a funeral, not even an auto-funeral, but a cenotaphic counter-funeral and the barrow becomes a counter-tomb: a failed mausoleum.

I wonder whether the words of Wiglaf also define the hoard as opposition to the joys of the lord's hall or contemporary shrine when he says 'I have been inside and seen everything/ amassed in the vault. I managed to enter/ although no great welcome awaited me under the earthwall' (lines 3087-90). Wiglaf here did not receive the accustomed greeting of a stranger at the threshold of a living lord's hall or active church, as Beowulf did when he visited Hrothgar in Heorot (lines 389-490), instead he received no welcome.

Stored, cthonic and inactive, the treasure is prevented by its curse from re-entering circulation and subsequently only following the dragon's death could it serve to honour Beowulf's passing. Thus, once we strip the poem of the tenacious grip of princely graves, we can allow the treasure to tell a different story: it is a collective cenotaphic memorial to a lost people and their lost halls and absent graves as much as to the 'windswept hearthstone' (line 2457). It thus becomes an inactive, cursed and guarded cache. As such, the treasure is oppositional to 
the ideal of lordly life in the hall and a vibrant church, but it is simultaneously the result of an counter-funeral in the sense that it was rendered inoperable for exchange, display and honouring the dead.

The fundamental point is that this is an empty tomb, like Christ's prior to His burial and following His ascent, but in this case, rather than a departed body, this treasure is awaiting a new body. In other words the funerary associations were yet to be fulfilled because of its hoarding and only acquired following the death of the dragon in relation to Beowulf's own death and funeral. Beowulf's 'bone house' (line 3147) is burnt and the treasure joins him; the body-less treasure and the treasure-less body are at this final stage of the poem conjoined in Beowulf's barrow. Thus, the treasure is key in creating a new 'house' for gold, 'useless to men as ever it was' (lines 3166-68). Both treasure and Beowulf 'had reached the end of the $\mathrm{road} /$ through the life they had been lent' (lines 2843-44): the treasure becomes a device for mourning and remembrance.

In summary, I contend that the dragon's treasure is not being portrayed as primarily funerary, but instead has a biography of successive significances, starting as counter-funerary and leading up to it final funerary reuse in the composition of Beowulf's own burial mound and obsequies. While the play on Christ's empty tomb would have been recognised for a Christian audience, this tomb goes through many stages of use. First, it is a cache in a chamber, then the antithesis of an oratory or crypt containing holy relics, the opposite of gifts selected to honour the dead at a high-status funeral and antithetical to the treasures on display in a lord's hall and in church settings.

The direct parallel is with the $8^{\text {th }}$-century Life of Saint Guthlac by Felix in which we are explicitly told that the chamber within a mound at Crowland, Lincolnshire, may have been revealed by treasure hunters. Guthlac uses this space to inhabit (Hutton 2009, 11; Semple 2013, 149-53). In this sense, the dragon's mound is the antithesis of the hermit's place of habitation which subsequently becomes his chapel and burial place but the parallel comes from it being a sign of antiquity and miraculous action. So the mounds of Guthlac and the dragon follow parallel paths. They both constitute caches for treasure, then residences for dangerous beasts and devils, then arena for heroic combat against these monsters, and then a setting for the hero's death and burial. Thus, the mound in the Life of Saint Guthlac runs a parallel course to the monument biography of the dragon's mound in Beowulf and the focus on dying rather than death itself. The secular appearance of the artefacts described might seem to contradict the idea of the crypt as parallel, yet I contend that in the later Anglo-Saxon landscape, subterranean and semi-subterranean mausolea and oratories as well as lord's halls were likely place to find stores of treasures. It was for this very reason that Viking raiders found halls and chuches so profitable for pillage from the late $8^{\text {th }}$ century.

\section{The Dragon's Materiality}

The dragon is the third component of the burial mound, a monstrous flying and fire-breathing creature described as a 'sky-roamer' (line 2830) and 'sky-winger' (line 2314) and a 'firedragon' (line 2333). Yet primarily the beast is described as a watchful but sleeping subterranean resident and guardian. Elsewhere in Anglo-Saxon literature, Semple outlines the association of Old English draugr with mounds and treasure, but also clefts and other subterranean spaces that together are hellish and wild, associated with exile and torment, but also concepts of the 'heathen' (the godless) (Semple 2013: 153; 178-9). In the poem, the dragon is 'the burning one who hunts out barrows' (line 2272), repeatedly described in relation to its subterranean presence near, but not upon, the treasure: as the 'guardian of the 
mound' (line 2302), 'hoard-watcher' (line 2303), 'cave-guard' (line 2525), 'mound-keeper' (line 2580), 'hoard-guard' (line 2594), 'barrow-dweller' (line 2841) and 'treasure-minder' (line 3133). The beast dominates the dark (line 2212) and only appears to cause fiery aerial destruction at night. Thus the dragon is a thief of sorts: the keeper of the mound is an uninvited resident and guardian for over three centuries, not the rightful owner of the treasure (line 2278). In searching for the treasure, the dragon encircles the mound's exterior (line 2296).

Yet the dragon is also an agent of death, seeking vengeance on those bound to the act of disturbing the treasure. The dragon's fiery breath and poisonous bite enact the first of two 'cremations' that Beowulf endures: the hero is consumed by fire through his skin and blood twice over; by dragon and by pyre. This duality is paralleled with the deposition of artefacts upon the pyre and in the mound built in Beowulf's honour.

Upon death, the dragon disappears, only to appear later to be hauled out of the mound tipped over the nearby sea-cliff (line 3118-20). Its corpse is an embodiment of the sinner's soulless cadaver; its fate worthy of a 'heathen' burial placed on the boundaries of territories and upon the foreshore (Reynolds 2009; Semple 2013, 195-203). It is also reminiscent of the fate of the pagan inhabitants of Sussex described by the Venerable Bede, who in famine cast themselves over cliffs (Sherley-Price (trans.) 1990, 226). Cliffs are thus a cursed place for heathen burial and dishonourable treatment of the unsaved dead.

Semple $(2013,145)$ notes a small selection of place-names that show that a connection between dragons and barrows was being mapped out in select parts of Anglo-Saxon England. Langlands and Reynolds (2011) suggest that the Oxfordshire linear earthwork, Grimesditch, and possibly the Uffington White Horse, were also interpreted as dragonesque. Wyrms certainly pervaded the Anglo-Saxon world and imagination. As Thompson $(2004,135)$ succinctly states: 'the dragon in Beowulf inhabits an ambiguous moral space: he is powerful and he may be inimical, but he is not diabolical'. Not wholly negative, Thompson suggests that ubiquitous serpentine imagery upon metalwork and sculpture suggests that wyrmas might be apotropaic through their intertwining bodies but also their watchfulness (Thompson 2004, 134; see also Williams 2011b). Thompson's study of literary evidence reveals the complex and varied natures of the wyrm from maggots to winged serpents, and this ubiquity and diversity is seen in the variety of media - including metalwork and stone sculpture - upon which dragons appear between the $7^{\text {th }}$ and $11^{\text {th }}$ centuries AD.

Any pre-Christian connotations of the serpent aside, this was a beast that was clearly multivalent and powerful and survived and expanded its repertoire of use across the conversion period (Hawkes 1997). Catherine Hills $(1997,297)$ astutely notes that archaeologists tend to focus on the 'real world' elements of the poem: 'No one has tried to dig up Grendel, his mother, or the dragon'. Still, she goes on to note that the dragon in the poem chimes with the serpentine art of the Early Middle Ages, yet I would suggest this falls short of the potential for archaeology to 'dig up' the dragon. Early medieval zoomorphic art is assumed from this perspective to be simply representations of imaginary monsters. In some instances, however, the art was more than that, the decoration held an agency through its animated, multi-sensory, tactile and embodied qualities. Animal art afforded real beastly presences on the surfaces of artefacts and architectures, watching, biting, encircling and hence guarding them as apotropaic and empowering agencies, demonstrating the power, authority and identities of those commissioning, wielding and exchanging them (Williams 2011b). 
It is from this perspective that we can understand the dragon as more than imaginary beast, but as a key ingredient of the materiality of the stone barrow in Beowulf. The dragons' symbolic ambiguity is manifest on a wide range of stone sculpture from across England. For example, there is an early version of a representation of St Michael slaying the dragon is known from Stinsford, Dorset (Cramp 2006, 113-14) and the rood screen at Bitton (Gloucestershire) shows a snake beneath the crucified Christ (Bryant 2012: 147-8). On crossshafts, we have the reptilian beasts on the base of Ramsbury 3 (Wiltshire) dated to the $9^{\text {th }}$ or $10^{\text {th }}$ century (Cramp 2006, 230) and the snakes threatening a human figure on two faces (A and C) of the Masham 3 (North Yorkshire) shaft fragment (Lang 2001, 172: 646 and 648).

More overtly commemorative contexts display serpents prominently, including Sockburn 3A (Cleveland), upon which a serpent looms over a rider holding a bird of prey - perhaps a secular portrait honouring the dead (Cramp 1984, 136-37, plate 710). Meanwhile the bound serpents from Ryedale: Middleton 1C and 2C (Lang 1984, 181-84, plates 672, 674, 678 and 680) and Sinnington 3A (Lang 1984, 208, plate 804), both North Yorkshire, are juxtaposed with images of lordly ideals: seated in his hall or hunting. Two serpents intertwine up the $10^{\text {th }}$-century cross-shaft (1A) from Lastingham, also North Yorkshire (Lang 1984, 167). The world serpent of Norse mythology is depicted on the $10^{\text {th }}$-century Gosforth cross (1D), Cumbria (Cramp and Bailey 1988, plates 305 and 306), and a serpent dripping poison on Loki also appears on this monument (1C) (Cramp and Bailey 1988, plates 301 and 304). Together, these examples reveal the serpent as agent of death and destruction, but also prefiguring redemption and resurrection.

Upon grave-slabs of the $10^{\text {th }}$ century, we find an overtly mortuary association with serpents guarding the bodies of the dead. As Thompson (2004) shows, dragonesque winged end-beasts frame the crosses on grave-slabs from York Minster (e.g. Minster 35A, 36A, 38A and 39A: Lang 1991, 72-74; plates 148, 152, 159 and 165, see also Thompson 2003; see also Shrewsbury St Mary 3: Bryant 2012, 79-81; 310-11). A weapon-bearing human figure (often identified as the dragon-slayer Sigurd) battles with two serpents on York Minster 34D (Lang 1984, 71-72; plate 147). Also, serpentine end-beasts adorn some of the $10^{\text {th }}$-century hogback stones - mortuary monuments that embody complex skeuomorphic transformations of architectural spaces - as upon Lythe 25, North Yorkshire (Lang 2001, 162-63; plates 553 and 556; see also Williams forthcoming), while serpents battle humans on Gosforth hogback 5C (Cramp and Bailey 1984, plate 327).

While this evidence reveals a range of significances to the dragon upon Anglo-Saxon commemorative stone monuments and architecture, it is sufficient to allow us to rethink the importance of the dragon's lithic habitation in Beowulf. We are left with the possibility that the materiality of the stone monument is key to the relationship with, and significance of, the simultaneously chthonic and aerial dragon. As well as secular and sacred artefacts bearing dragon designs such as the Anglian helmet from Coppergate, York (Kitzinger 1993, 4), there are a range of stone sculptures that render serpentine beasts as guardians on the thresholds to holy places, such as the western entrance porch to the church at Monkwearmouth built in AD 674 (Monkwearmouth 8a-b: Cramp 1984, 125-6, plates 112-13; Fig. 2) and its Late Antique funerary chapel predecessor at Poitiers: the Hypogée des Dunes (Kitzinger 1993: 4). Hence, serpents could be both threatening and binding architectural forces: Christian representations of the devil and/or guardians of the living and the dead in the medium of stone. At St Mary Deerhurst and St Oswald's Gloucester, the rare survival of downward- and outward-facing animal heads on label stops and prokrossos (projecting hood above the apex of an arch) 
strongly suggest that protective beasts were widespread features of Anglo-Saxon church architecture, guarding apertures and thresholds (Bryant 2012, 175-85). This theme seems to extend to mortuary monuments with the tenth-century hogback tombs (Williams forthcoming).

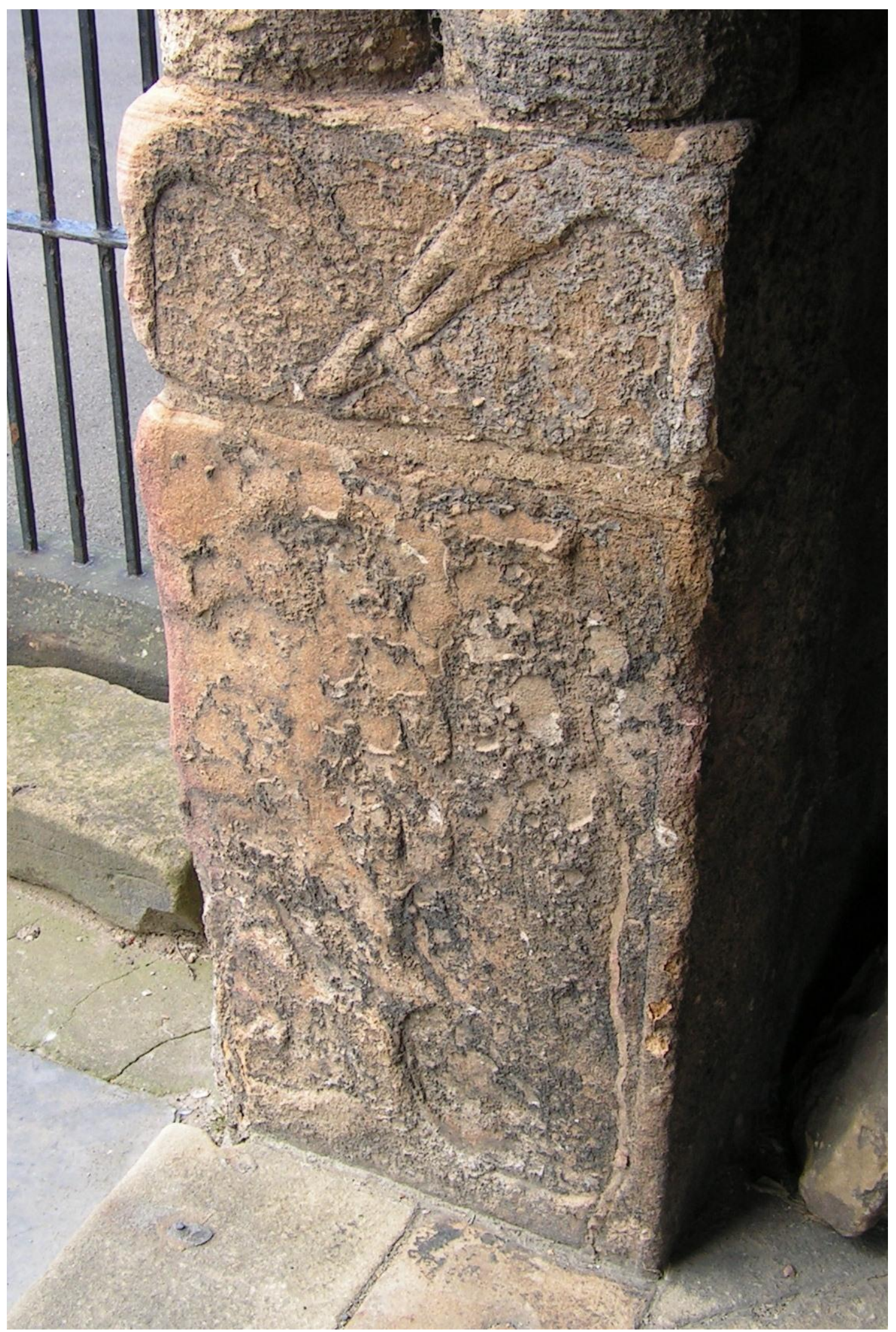


Figure 2: The late $7^{\text {th }}$-century serpentine beasts on the western threshold of the Anglo-Saxon monastic church at Monkwearmouth. Photograph: Howard Williams, 2006

Important here is the poem's impression that the dragon permeates the stone barrow, coming and going at will and seeming using other entrances to that utilised by the thief, Beowulf and Wiglaf. Seemingly inhabiting the mound itself, encircling, above and below the chamber, the poem implies the dragon lived beneath the earth but separate from the treasure in some fashion (line 2319). This is evident in the fact that the dragon was not an occupant of the chamber in which the thief found a golden vessel but that the chamber was 'close to his dreaming head' (line 2290). It was from the vaults itself - like the $9^{\text {th }}$-century beasts label stops around apertures at Deerhurst or the end-beasts upon hogback stones - that the dragon kept watch before he 'rippled down the rock' to discover human footprints of the intruder, suggesting a position on the side or above the chamber (line 2288). The beast was said to go 'back to the hoard' (line 2319) and to be 'secure/ in the vaults of his barrow' (line 2322-23) but this does not necessarily mean upon or among the hoard itself.

Even in death, the dragon does not appear to reside in the hoard, for Wiglaf does not encounter the serpent's corpse upon re-entering this space (line 2771-2), despite the beast's body being subsequently found and cast into the sea prior to Beowulf's funeral. Hence, we seem to have implied at least two chambers within the mound, one for the dragon, one for the hoard. Or else, alternatively, when hearing Beowulf's voice, the dragon does not rise up from the floor of the chamber but instead 'the breath of the monster/ burst from the rock. There was a rumble underground' (lines 2557-8), implying the dragon was outside the chamber, inside the rock itself, seemingly burrowing worm-like through the stony material of the barrow and over its surfaces. Equally, given the aforementioned hot stream issuing forth from the barrow, the dragon might be seen as a water-beast akin to those Beowulf fought previously in his swim against Breca and once again grappled with in the mere before the fight with Grendel's mother (lines 575; 1425-41; 1510). After all, the dragon ends up being returned to the water after its death and so it is possible that the dragon is conceived as interchangeably a monster of the dark earth, night-time air and subterranean water: a resident of the barrow, not a resident of the chamber alone.

This leads us to speculate as to whether the very idea of the dragon in Beowulf derives from serpentine sculpture inscribed upon and guarding the stone portals, pillars and crosses associated with later Anglo-Saxon halls, churches and (given the discussion thus far) perhaps stone subterranean spaces specifically. After all, these are nothing other than real dragons, three dimensional beasts originally painted in multiple vivid colours that would seem to emerge out of, and moving over, and watch over the spaces and thresholds of churches, chapels, crypts and tombs. Again, contemporary church architecture might provide a ready inspiration for the dragon's lair, more than any Neolithic chambered tomb.

\section{Conclusion}

Neolithic megalithic architectures persisted through the Middle Ages as landmarks, attracting burials, names and other activities. Yet this chapter argues that it is simplistic, misleading, anachronistic and theoretically stifling to equate the dragon's barrow exclusively with Neolithic megalithic architecture. Indeed, the desire to see $7^{\text {th }}$-century chamber graves reflected in the treasure of the dragon's mound, and to see a Neolithic tomb in its stone architecture, might be seen to be products of a Victorian desire to regard the poem as a 'pagan survival' as well as to see the Saxons as an immigrant race supplanting the monuments of the ancient British. Even more so, it is problematic to regard the dragon's 
mound specifically as a single-phase funerary structure. Instead, the dragon's mound was significant through successive stages of the poem's narrative, a place of loss, a cache, a monstrous dwelling, a place of exile, heroic conflict, death and only then part of the landscape of the hero's funeral whose mound was raised close by. The dragon's mound possessed a biography of uses and reuses that made sense within early medieval heroic, but also biblical and hagiographical, literary structures, making it both a place of infamy and fame, torment and deliverance. This suggests that, where Neolithic megaliths persisted in the landscape of early medieval Europe, they might be apprehended in relation to the experience of building and encountering semi-subterranean and subterranean baptisteries, oratories and mausolea in ecclesiastical landscapes. These were lithic spaces containing treasures and guarded by zoomorphic aptropaic art. The stone barrow portrayed in Beowulf is framed as contrapuntal to the architectures of the royal and holy dead as much as the halls of lords (Semple 2013, 143-92).

This reappraisal of the dragon's mound in Beowulf challenges overly simplistic readings of the archaeological and literary biographies of megalithic monuments in early medieval Europe and promotes the need for contextual engagements with contemporary architectures (those built and still in use during the $7^{\text {th }}$ to $11^{\text {th }}$ centuries AD) to draw interpretations that account for the varied and complex material engagements and perceptions of Neolithic tombs in later landscapes. The biography of the dragon's mound in the poem is indeed outstanding, for the very reason that it is not primarily a Neolithic megalithic tomb, but possesses a literary biography counterpoised with a nexus of stone architectures - ancient and ruined, recent and intact, experienced and encountered in the early medieval landscape.

\section{Acknowledgements}

I am very grateful for the constructive comments of Ruth Nugent and Michael Shapland upon an earlier draft of this chapter. All errors are the author's responsibility.

\section{References}

Bailey, R. and Cramp, R. 1988. Corpus of Anglo-Saxon Stone Sculpture Volume II: Cumberland, Westmorland and Lancashire North-of-the-Sands. Oxford: Oxford University Press.

Biddle, M. and Kjølbye-Biddle, B. 2001. Repton and the 'Great Heathen Army', 873-4. In: J. Graham-Campbell, R. Hall, J. Jesch and D. N. Parsons (eds) Vikings and the Danelaw. Oxford: Oxbow: 45-96.

Bidwell, P. 2010. A Survey of the Anglo-Saxon crypt at Hexham and its Reused Roman Stonework. Archaeologia Aeliana 39: 53-145.

Bradley, R. 1998. Ruined Buildings, Ruined Stones: Enclosures, Tombs and Natural Places in the Neolithic of South-West England. World Archaeology 30(1): 13-22.

Bradley, S. (ed. and trans.) 1982. Anglo-Saxon Poetry, London: Dent.

Bryant, R. 2012. Corpus of Anglo-Saxon Stone Sculpture Volume X The Western Midlands: Gloucestershire, Herefordshire, Shropshire, Warwickshire and Worcestershire. Oxford: Oxford University Press. 
Cramp, R. 1957. Beowulf and Archaeology. Medieval Archaeology 1: 57-77.

Cramp, R. 1984. Corpus of Anglo-Saxon Stone Sculpture Volume I: County Durham and Northumberland, 2 Parts, Oxford: Oxford University Press.

Cramp, P. 2006. Corpus of Anglo-Saxon Stone Sculpture Volume VII: South-West England, Oxford: Oxford University Press.

Grinsell, L. V. 1991. Wayland the Smith and his Relatives: a Legend and its Topography, Folklore 102(2): 235-6.

Hawkes, J. 1997. Symbolic Lives: The Visual Evidence. In: J. Hines (ed.) The Anglo-Saxons from the Migration Period to the Eighth Century. Woodbridge: Boydell: 311-344.

Hills, C. M. 1997. Beowulf and Archaeology. In: R. E. Bjork and J. D. Niles (eds) A Beowulf Handbook. Exeter: University of Exeter Press: 291-310.

Hines, J. 2008. Voices in the Past: English Literature and Archaeology. Woodbridge: Boydell.

Hines, J. 2011. Literary Sources and Archaeology. In: H. Hamerow, S. Crawford and D. Hinton (eds) Oxford Handbook of Anglo-Saxon Archaeology. Oxford: Oxford University Press: $368-85$.

Hunter, M. 1974. Germanic and Roman Antiquity and the Sense of the Past in Anglo-Saxon England. Anglo-Saxon England 3: 29-50.

Hutton, R. 2009. Megaliths and Memory. In: J. Parker (ed.) Written in Stone: The Cultural Reception of British Prehistoric Monuments. Newcastle: Cambridge Scholars Press, pp. 1022.

Holtorf, C. 1996. Towards a Chronology of Megaliths: Understanding Monumental Time and Cultural Memory, European Journal of Archaeology. 4: 119-52.

Kitzinger, E. 1993. Interlace and Icons: Form and Function in Early Insular Art. In: R. M. Spearman and J. Higgitt (eds) The Age of Migrating Ideas: Early Medieval Art in Northern Britain and Ireland. Edinburgh: National Museums of Scotland: 3-15.

Lang, J. 1984. The Hogback: a Viking Colonial Monument. In: S. C. Hawkes, J. Campbell and D. Brown (eds) Anglo-Saxon Studies in Archaeology and History 3. Oxford: Oxford University Committee for Archaeology: 83-176.

Lang, J. 1991. Corpus of Anglo-Saxon Stone Sculpture Volume III: York and Eastern Yorkshire. Oxford: Oxford University Press.

Lang, J. 2001. Corpus of Anglo-Saxon Stone Sculpture Volume VI: Northern Yorkshire. Oxford: Oxford University Press.

Owen-Crocker, G. 2000. The Four Funerals in Beowulf. Manchester: University of Manchester Press. 
Price, N. 2010. Passing into Poetry: Viking-Age Mortuary Drama and the Origins of Norse Mythology. Medieval Archaeology 54: 123-156.

Reynolds, A. 2009. Anglo-Saxon Deviant Burial Customs. Oxford: Oxford University Press.

Reynolds, A. and Langlands, A. 2011. Travel as communication: a consideration of overland journeys in Anglo-Saxon England. World Archaeology 43(3): 410-27.

Rodwell, W. 2001. Wells Cathedral: Excavations and Structural Studies, 1978-93, London: English Heritage. 2 Volumes.

Scarre, C. 2007. The Megalithic Monuments of Britain and Ireland. London: Thames and Hudson.

Semple, S. 1998. A Fear of the Past: the Place of the Prehistoric Burial Mound in the Ideology of Middle and Later Anglo-Saxon England. World Archaeology, 30(1): 109-26.

Semple, S. 2004. Illustrations of Damnation in Late Anglo-Saxon Manuscripts. Anglo-Saxon England 32: 231-45.

Semple, S. 2013. Perceptions of the Prehistoric in Anglo-Saxon England: Religion, Ritual and Rulership in the Landscape. Oxford: Oxford University Press.

Sherley-Price, L. 1990. Bede: Ecclesiastical History of the English People, $3^{\text {rd }}$ Edn. London: Penguin.

Taylor, H. 1987. St Wystan's Church, Repton, Derbyshire, Derbyshire: A Reconstruction Essay. Archaeological Journal 144: 204-45.

Thompson, V. 2003. Memory, Salvation and Ambiguity. In: H. Williams (ed.) Archaoelogies of Remembrance: Death and Memory in Past Societies. New York: Kluwer/Plenum: 215-26.

Thompson, V. 2004. Dying and Death in Later Anglo-Saxon England. Woodbridge: Boydell.

Vejby, M. D. 2012. Reinterpreting the Iron Age and Roman Reuse of Megalithic Tombs in Atlantic Europe. Reading: Unpublished Doctoral Thesis, University of Reading.

Webster, L. 1998. Archaeology and Beowulf. In: B. Mitchell and F. C. Robinson (eds) Beowulf: An Edition: Oxford: Wiley: 183-94.

Webster, L. 2000. Versions of Treasure in the Early Anglo-Saxon World. In: E. Tyler (ed.) Treasure in the Early Medieval West. Woodbridge: York Medieval Press: 49-60.

Williams, H. 1998. Monuments and the Past in early Anglo-Saxon England. World Archaeology 30 (1): 90-108.

Williams, H. 2006. Death \& Memory in Early Medieval Britain, Cambridge: Cambridge University Press. 
Williams, H. 2011a. Remembering Elites: Early Medieval Stone Crosses as Commemorative Technologies, in L. Boye, P. Ethelberg, L. Heidemann Lutz, S. Kleingärtner, P. Kruse, L. Matthes and A. B. Sørensen (eds) Arkaologi i Slesvig/Archäologie in Schleswig. Sonderband “Det 61. Internationale Sachsensymposion 2010” Haderslev, Denmark. Neumünster: Wachholtz: 13-32.

Williams, H. 2011b. The Sense of Being Seen: Ocular Effects at Sutton Hoo, Journal of Social Archaeology 11(1): 99-121.

Williams, H. (in press 2015) Hogback tombs: the materiality of solid spaces. In: H. Williams, J. Kirton and M. Gondek (eds) Early Medieval Stone Monuments: Materiality, Biography, Landscape. Woodbridge: Boydell and Brewer

Wright, T. 1847. On the Legend of Weland the Smith. Archaeologia 32: 315-24. 